\title{
Proteins involved in regulating bone invasion in skull base meningiomas
}

\author{
Fateme Salehi • Shahrzad Jalali • Ryan Alkins • \\ Joon-Il Lee • Shelly Lwu • Kelly Burrell • Fred Gentili • \\ Sidney Croul • Gelareh Zadeh
}

Received: 15 July 2012 / Accepted: 18 October 2012 / Published online: 13 December 2012

(C) The Author(s) 2012. This article is published with open access at Springerlink.com

\begin{abstract}
Background Bone invasive skull base meningiomas are a subset of meningiomas that present a unique clinical challenge due to brain and neural structure involvement and limitations in complete surgical resection, resulting in higher recurrence and need for repeat surgery. To date, the pathogenesis of meningioma bone invasion has not been investigated. We investigated immunoexpression of proteins implicated in bone invasion in other tumor types to establish their involvement in meningioma bone invasion.

Methods Retrospective review of our database identified bone invasive meningiomas operated on at our institution over the past 20 years. Using high-throughput tissue microarray (TMA), we established the expression profile of osteopontin (OPN), matrix metalloproteinase-2 (MMP2), and integrin beta-1 (ITGB1). Differential expression in tumor cell and vasculature was evaluated and comparisons were made between meningioma anatomical locations.

Results MMP2, OPN, and ITGB1 immunoreactivity was cytoplasmic in tumor and/or endothelial cells. Noninvasive
\end{abstract}

F. Salehi $\cdot$ R. Alkins $\cdot$ J.-I. Lee $\cdot$ S. Lwu $\cdot$ F. Gentili $\cdot$ G. Zadeh $(\bowtie)$

Division of Neurosurgery, Toronto Western Hospital,

University of Toronto,

399 Bathurst Street, 4W-439,

Toronto, ON M5T 2S8, Canada

e-mail: Gelareh.Zadeh@uhn.ca

F. Salehi

e-mail: fsalehi@uwo.ca

S. Jalali $\cdot$ K. Burrell $\cdot$ G. Zadeh

Arthur and Sonia Labatt Brain Tumour Research Centre,

Hospital for Sick Children, University of Toronto,

Toronto, Canada

S. Croul

Department of Pathology (Neuropathology),

University Health Network,

Toronto, Ontario, Canada transbasal meningiomas exhibited higher vascular endothelial cell MMP2 immunoexpression compared to invasive meningiomas. We found higher expression levels of OPN and ITGB1 in bone invasive transbasal compared to noninvasive meningiomas. Strong vascular ITGB1 expression extending from the endothelium through the media and into the adventitia was found in a subset of meningiomas.

Conclusions We have demonstrated that key proteins are differentially expressed in bone invasive meningiomas and that the anatomical location of bone invasion is a key determinant of expression pattern of MMP1, OPN, and ITGB1. This data provides initial insights into the pathophysiology of bone invasion in meningiomas and identifies factors that can be pursued as potential therapeutic targets.

Keywords Bone invasion $\cdot$ Integrins $\cdot$ Matrix metalloproteinase $\cdot$ Meningioma $\cdot$ Osteopontin $\cdot$ Transbasal meningioma

\section{Introduction}

Meningiomas are dural-based intracranial neoplasms that are thought to arise from arachnoid cap cells. The majority of meningiomas are benign tumors with only approximately $5 \%$ exhibiting features of malignancy [2]. The World Health Organization (WHO) classifies meningiomas into three grades, with grade I comprising $90 \%$ of the tumors and exhibiting benign histopathological features, grade II showing atypical features, and grade III having anaplastic or malignant features [39]. Histopathological features associated with aggressive behavior include increased cell density, a higher nuclear-tocytoplasmic ratio, a sheet-like growth pattern, prominent nucleoli, elevated mitotic index, and necrosis. The presence of brain invasion is a feature considered to predict aggressive clinical behavior and recurrence, and is more recently used as a diagnostic criterion for WHO grade II designation [39]. 
A subset of meningiomas invade bone, create significant hyperostosis, and infiltrate adjacent neural and soft tissue structures $[2,5,34]$. In such cases, the proportion of the tumor growing in the bone and soft tissues can in fact be much larger than the intradural component, suggesting preferential bony tropism. Bone invasion is not factored into the WHO criterion for grading of meningiomas, however, the extent of bone invasion can bear directly on the clinical behavior of meningiomas, and more importantly, patient outcome. Bone-invasive skull base meningiomas pose a specific clinical challenge, as incomplete tumor resection carries both an increased risk of compromise of vital vascular and neural structures in addition to the risk of recurrence.

To date, there have been no studies that focus on the pathophysiology of bone invasion and bone tropism in meningiomas. Integrins, OPN, and MMPs are thought to play key regulatory roles in bone invasion and osteolytic metastasis in other tumors such as breast, prostate, and lung [7-9, 13-15, 20, $22,32,50]$; however, what role, if any, these molecules play in the bony tropism of meningiomas is not known. As a first step toward understanding the molecular mechanisms of bone invasion, we focused our study on distinct clinical subpopulations of skull base meningiomas that exhibit characteristic bone tropism. Based on clinical, radiological, and surgical characteristics, we defined two categories of skull base bone-invasive meningiomas: spheno-orbital and transbasal anterior skull base meningiomas, with their control counterparts being sphenoid wing and noninvasive anterior skull base meningiomas, respectively. We used TMA to analyze the expression profile of MMP2, OPN, and ITGB1 in these tumors.

\section{Materials and methods}

\section{Tumor samples}

Following institutional research ethics board approval, we reviewed a database of all surgically resected meningiomas from the past 20 years at our institution. Radiological and surgical criteria were used to select bone-invasive spheno- orbital or transbasal anterior skull base tumors and their control counterparts, sphenoid wing and noninvasive anterior skull base meningiomas, respectively. We chose to study only WHO grade I meningiomas to avoid bias due to tumor grade. Demographic data representing boneinvading and noninvading skull base meningiomas are summarized in Table 1.

\section{TMA construction}

Stained slides and formalin-fixed, paraffin-embedded, tissue specimens were obtained from our archives, and original diagnoses were reviewed by neuropathology (SC). Regions of representative tumor were identified on the slides and the corresponding areas of tissue circled on paraffin blocks. TMA construction was performed with a semi-automated tissue arrayer (Pathology Devices, Westminster, MD, USA) using a $1.5-\mathrm{mm}$ coring needle. The sample cores were embedded in a single paraffin block. A control hematoxylin and eosin (H\&E) stain was performed and the cores were reviewed by neuropathology for tumor integrity.

\section{Immunohistochemistry}

Formalin-fixed paraffin-embedded sections of $4 \mu \mathrm{m}$ were dewaxed in xylene and brought down to water through graded ethanol solutions. Antigen retrieval was achieved by incubation in citrate buffer of $\mathrm{pH} 6.0$ for $15 \mathrm{~min}$. Endogenous peroxidase and biotin activities were blocked with $3 \%$ hydrogen peroxide and an avidin/biotin blocking kit, respectively. Nonspecific reactivity was blocked by incubation with $10 \%$ normal goat serum. Tissue was incubated at room temperature with corresponding antibodies (ITGB1, Abcam; OPN, Lab Vision; MMP2, Lab Vision, and CD31, Lab Vision) with previously optimized concentrations. This was followed by incubation with a biotinylated secondary antibody (Vector labs, Burlingame, CA, USA) for $30 \mathrm{~min}$ and horseradish peroxidase-conjugated Ultra Streptavidin labeling reagent (ID Labs, London, ON) for $30 \mathrm{~min}$. After washing in Tris buffered solution (TBS), color development

Table 1 Demographic data representing meningiomas in the present study

\begin{tabular}{|c|c|c|c|c|c|c|c|c|c|}
\hline Meningioma location & $n$ & Female & Male & Age & Follow-up (months) & Mass effect & Seizure & Diplopia & Visual acuity \\
\hline Spheno-orbital invasive & 8 & 6 & 2 & 48.3 & $31(2-68)$ & $8(100 \%)$ & $1(13 \%)$ & $1(13 \%)$ & $3(38 \%)$ \\
\hline Sphenoid wing noninvasive & 18 & 13 & 5 & 55.4 & $33(0-71)$ & $17(94 \%)$ & $5(28 \%)$ & $1(6 \%)$ & $4(22 \%)$ \\
\hline Transbasal invasive & 10 & 6 & 4 & 53.4 & $90(0-212)$ & $10(100 \%)$ & $2(20 \%)$ & $2(20 \%)$ & $5(10 \%)$ \\
\hline Transbasal noninvasive & 23 & 16 & 7 & 42.5 & $28(0-194)$ & $22(96 \%)$ & $7(30 \%)$ & $2(9 \%)$ & $8(35 \%)$ \\
\hline All invasive & 18 & 12 & 6 & 56.8 & $52(0-212)$ & $21(100 \%)$ & $3(14 \%)$ & $3(14 \%)$ & $8(38 \%)$ \\
\hline All noninvasive & 41 & 29 & 12 & 49 & $30.5(0-194)$ & $39(95 \%)$ & $12(29 \%)$ & $3(7 \%)$ & $12(29 \%)$ \\
\hline Total & 59 & 41 & 18 & 52.9 & 41.3 & $60(97 \%)$ & $15(24 \%)$ & $6(10 \%)$ & $20(32 \%)$ \\
\hline
\end{tabular}


was done with NovaRed solution (Vector Labs Cat\# SK4800). Counterstaining was performed with Mayer's hematoxylin. The slides were then dehydrated in graded ethanol solutions, cleared in xylene, and mounted in Permount (Fisher, Pittsburg, PA, USA, cat\# SP15-500).

\section{Microscopy and analysis}

The slides were scanned and visualized using the MIRAX digital slide scanning application (Carl Zeiss MicroImaging $\mathrm{GmbH}$, Jena, Germany). The immunohistochemical expression of OPN, ITGB1, and MMP-2 were semi-quantitatively scored for intensity and percentage of immunoreactive cells. Intensity was graded from 0 to 2 ( 0 : none, 1 : mild/moderate, 2: strong), and percentage was scored from 0 to 3 (0: none, 1: $<25 \%, 2: 25-50 \%, 3:>50 \%)$. The intensity and percentage scores were then combined to produce a composite immunoscore [36]. Where there was more than one specimen available, an average of the immunoscores for the specimens was calculated.

Statistical analysis

Student's $t$ test assuming unequal variances was used to evaluate differences between groups. A $p$ value of $<0.05$ was assumed to be significant.

\section{Results}

Clinicopathological correlations

Patient demographics and clinical information including pattern of tumor invasion, presenting symptoms, pathological grade, radiological data, and follow-up information was recorded as summarized in Table 1. No differences were found in patient age, sex, meningioma progression, or pathological grade between the two skull base bone-invasive meningioma groups and their control counterparts.
Immunohistochemical analysis of MMP2, OPN, and ITGB1

\section{$M M P 2$}

MMP2 was expressed to a variable degree in tumor cell cytoplasm and the immunoscores of MMP2 tumor expression showed no significant difference between sphenoorbital tumors and the control sphenoid wing tumors and between transbasal and anterior skull base control meningiomas (Table 2). MMP2 expression within tumor vessels was restricted to the endothelium and did not involve the media or adventitia (Table 2). There was significantly lower vascular immunoexpression by bone-invasive transbasal tumors compared to control anterior skull base $(p=0.004$ one-tailed) (Fig. 1a, b).

\section{$O P N$}

OPN was expressed to a variable degree in tumor cell cytoplasms with the majority of tumors showing only low levels of expression. The immunoscores of OPN in tumor cells showed no significant difference between sphenoorbital tumors and the control sphenoid wing tumors and between transbasal and anterior skull base control meningiomas (Table 2). Vessels demonstrated OPN immunoreactivity, found within the vascular media not the intima or adventitia (Fig. 1d). While statistical comparisons of invasive spheno-orbital vascular to controls failed to reach significance (Table 2), the comparison of invasive transbasal vascular staining to controls demonstrated a significantly greater immunoscore for OPN in the invasive group of tumors $(p=0.037$ one-tailed) (Table 2$)$.

\section{ITGB1}

ITGB1 was expressed to a variable degree within the cytoplasm of tumor cells. The immunoscore of ITGB1 expression within tumor cells showed no significant difference between spheno-orbital tumors and the control sphenoid wing tumors (Table 2). However, there was significantly

Table 2 Immunohistochemical (IHC) staining scores (mean \pm SD) of MMP2, OPN, and ITGB1 in ISB (invasive skull base), NISB (noninvasive skull base), IS (invasive sphenoid wing), and NIS (noninvasive sphenoid wing) meningiomas

\begin{tabular}{|c|c|c|c|c|c|c|c|c|c|c|}
\hline \multirow[b]{2}{*}{ IHC stain } & \multicolumn{5}{|l|}{ Tumor } & \multicolumn{5}{|l|}{ Vessel } \\
\hline & $\begin{array}{l}\text { ISB } \\
\text { Mean } \pm \text { SD }\end{array}$ & $\begin{array}{l}\text { NISB } \\
\text { Mean } \pm \text { SD }\end{array}$ & & $\begin{array}{l}\text { IS } \\
\text { Mean } \pm \text { SD }\end{array}$ & $\begin{array}{l}\text { NIS } \\
\text { Mean } \pm \text { SD }\end{array}$ & $\begin{array}{l}\text { ISB } \\
\text { Mean } \pm \text { SD }\end{array}$ & $\begin{array}{l}\text { NISB } \\
\text { Mean } \pm \text { SD }\end{array}$ & & $\begin{array}{l}\text { IS } \\
\text { Mean } \pm \text { SD }\end{array}$ & $\begin{array}{l}\text { NIS } \\
\text { Mean } \pm \text { SD }\end{array}$ \\
\hline MMP2 & $1.8 \pm 3.9$ & $2.5 \pm 1.8$ & & $1.6 \pm 0.6$ & $1.4 \pm 1.9$ & $4 \pm 8$ & $6 \pm 0 *$ & $p=0.004$ & $6 \pm 0$ & $5.2 \pm 3.2$ \\
\hline OPN & $2.3 \pm 7.6$ & $1.7 \pm 3.7$ & & $2.4 \pm 3.8$ & $2.4 \pm 6.5$ & $4.3 \pm 6.2$ & $2.3 \pm 4.3 *$ & $p=0.037$ & $4.2 \pm 5.8$ & $3.67 \pm 6.4$ \\
\hline ITGB1 & $4.6 \pm 6.2$ & $2.5 \pm 5.5 *$ & $p=0.035$ & $2.6 \pm 4.6$ & $4.2 \pm 6.1$ & $5.3 \pm 1.5$ & $5 \pm 3$ & & $4.2 \pm 5.8$ & $5.5 \pm 2.3$ \\
\hline
\end{tabular}

Asterisk $\left(^{*}\right)$ indicates statistically significant differences 
Fig. 1 Immunohistochemical expression of MMP2, OPN, and ITGB1 in bone invasive and noninvasive meningiomas (original magnification $\times 400$ ). a Low vascular MMP immunoexpression in a boneinvading transbasal meningioma. b High vascular MMP immunoreactivity in a noninvading skull base meningioma. The arrows indicate vascular immunostaining. c Low vascular OPN immunoexpression in a noninvading skull base meningioma. d High vascular OPN immunopositivity in a bone-invading transbasal meningioma. The arrows indicate vascular immunostaining. $\mathbf{e}$ Low tumoral ITGB1 immunoreactivity in a noninvading skull base meningioma. f High tumoral ITGB1 immunoexpression in a bone-invading transbasal meningioma. $\mathbf{g}$ Low vascular ITGB1 immunopositivity in a noninvading skull base meningioma. $\mathbf{h}$ High vascular ITGB1 immunoreactivity in a bone-invading transbasal meningioma in multiple layers extending from the endothelium through the media and into the adventitia. The arrows indicate vascular immunostaining
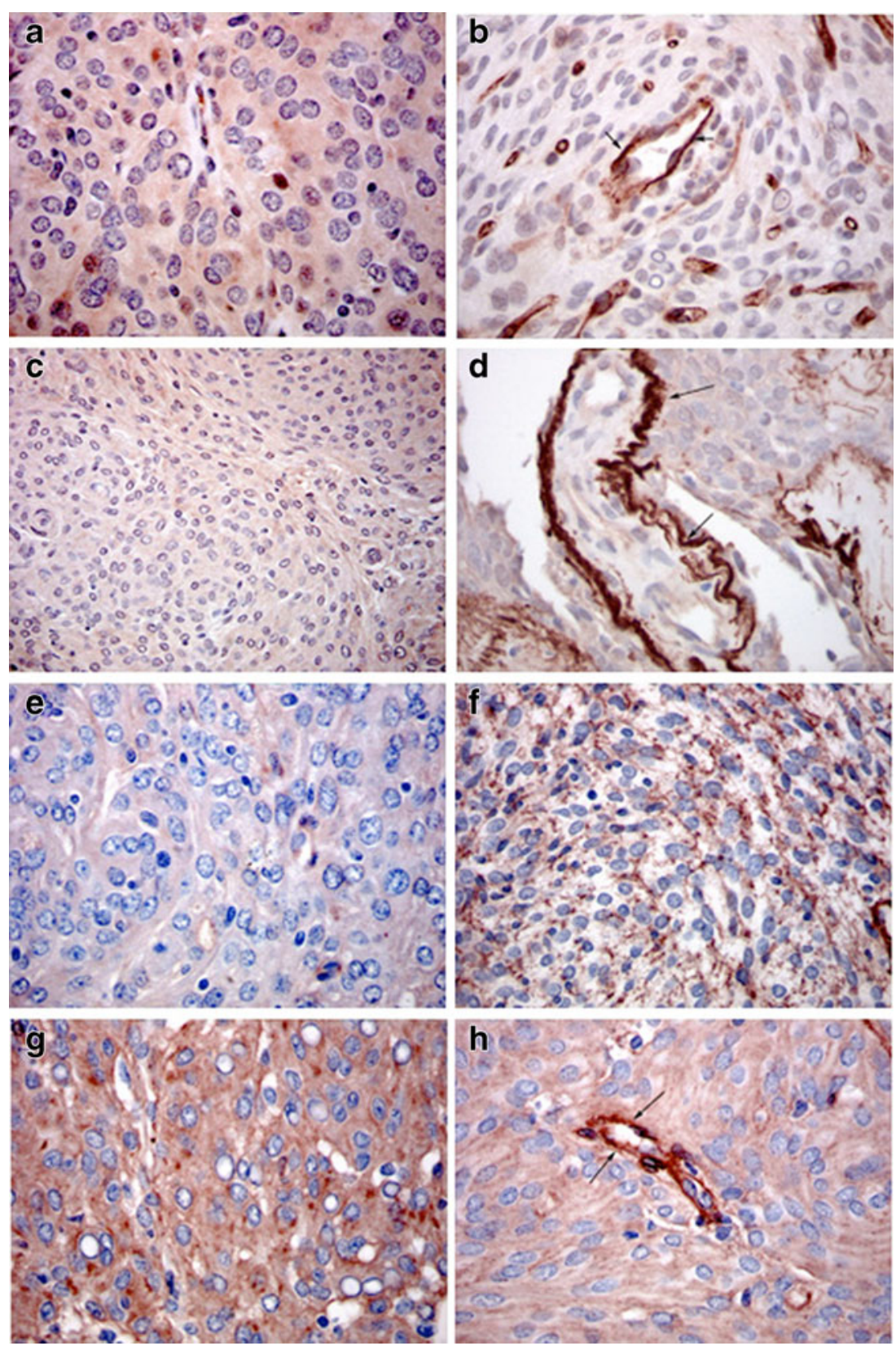

greater ITGB1 expression by invasive transbasal tumor cells over anterior skull base controls ( $p=0.035$ one-tailed) (Fig. 1e, f). Vessels within the tumor demonstrated high levels of ITGB1 in multiple layers extending from the endothelium through the media and into the adventitia (Fig. 1h). Nonetheless, immunoscores showed no difference between the vascular expression of either spheno-orbital or transbasal tumors and their respective controls (Table 2).

\section{Discussion}

Meningiomas make up approximately a one-fourth of all intracranial tumors and the WHO identifies 12 distinct histopathological subtypes [2, 12]. The molecular mechanisms of tumor growth and malignant progression are poorly understood and research results have been discordant. This is in part due to the fact that meningiomas are a large heterogeneous group of tumors classified histologically without a molecular or genetic basis [29]. Focusing on studying specific clinical subclasses of meningiomas, as we have done with bone invasion, can potentially help eliminate the heterogeneity in the studies and improve our understanding of the biology of meningiomas. We examined the differential expression profile of MMP2, OPN, and ITGB1 in two subclasses of bone-invasive meningiomas, spheno-orbital and transbasal anterior skull base, and established a distinct anatomical basis to the expression profile of these known bone-modulating factors. 


\section{MMP2}

MMPs are a family of zinc-dependent peptidases that mediate degradation of extracellular matrix components. MMPs are implicated in tumor cell growth, invasion, and metastasis [11]. The biological role and functional contribution of MMPs is complex and their role in meningiomas is far from established. Previous studies have focused on establishing the role of MMP2 in meningiomas, in particular as it relates to tumor recurrence, brain invasion, and peritumoral edema, and the data is conflicting $[10,19,21,23,24,26,28-31$, 48]. Though some studies found higher MMP 2 expression levels in recurrent meningiomas [28, 48], others have found no association between meningioma grade and MMP2 levels [29]. No correlation between MMP2 expression level and brain-invasive potential of meningiomas has been found to date $[23,24,26]$. Studies focused on the predictive potential of MMP2 on meningioma peritumoral edema have been contradictory, with Paek et al. [30] suggesting a positive association, whereas Panagopolous et al. [31] noted no such association. Yet Jaalinoja et al. [19] found no MMP-2 expression in benign meningiomas altogether.

MMP2 expression has been shown to vary with different meningioma histological subtypes [12, 37]. Rooprai et al. [37] reported the weakest MMP2 expression in meningothelial meningiomas, with the fibroblastic subtype exhibiting the strongest MMP2 expression. Fevre-Montange, using microarray analysis of fibroblastic and meningothelial meningiomas, found MMP2 to be one of the three signature genes that distinguished fibroblastic meningiomas, with the other two signature factors being tenascin and fibulin-1 (FBLN1) [12]. However, others have found no association between meningioma subtype and MMP2 immunoexpression [28, 48]. The variability in results of MMP2 is in part due to meningiomas being a large heterogeneous group of tumors, classified histologically without a molecular or genetic basis and in part due to lack of uniformity in methodology, including use of antibodies and immunohistochemical scoring methods [33].

We found no difference in MMP2 expression between bone-invasive and noninvasive skull base meningiomas by tumor cells. There is, however, a distinct upregulation in vascular expression of MMP2 in noninvasive anterior skull base meningiomas compared to transbasal bone invasive skull base meningiomas. This elevated vascular MMP2 was not seen in the spheno-orbital group, suggesting that anatomical location of bone invasion is an important determinant of proteins involved in regulating their growth, vascular proliferation, and potentially osteolytic activity. Despite the popular assumption that MMPs promote tumor invasion and growth, a recent study revealed that MMP2 overexpression in astrocytoma cells inhibited tumor growth and increased vascular destabilization [44]. The investigators hypothesized that MMP2 may target the activity of other pro- and antiproliferative factors, thereby inhibiting tumor cell proliferation in vivo [44]. Our findings of higher vascular MMP2 expression in noninvasive meningiomas could potentially point towards an inhibitory role for this matrix metalloproteinase in bone invasion through vascular destabilization.

\section{OPN}

OPN has been implicated in bone invasion in a number of cancer types and other intracranial tumors [45]. A recent study has proposed OPN expression as a negative prognostic indicator for recurrence of WHO grade I meningiomas [42] during a mean follow-up of 23 nonrecurrent and 9 recurrent meningiomas. As WHO classification does not include bone invasion as one of the criteria, it is unclear from this study if the higher recurrence rate was associated with bone invasion. Recently, Barresi et al. [3] noted OPN expression in psammoma bodies and calcifications, but also within noncalcified nonpsammomatous neoplastic cells of osteoblastic meningiomas, which are benign indolent tumors, suggesting that the findings of Tseng et al. in regard to OPN as a potential negative prognostic indicator should be interpreted with caution [46].

Several studies support the role of OPN in promotion of bone invasion in other tumor types $[1,3,4,6,7,15-18,20$, $22,25,27,38,40,41,47,49,51]$. First, OPN is shown to increase bone resorption by osteoclasts in breast carcinomas [22]. Equally, serum OPN levels and immunoexpression are higher in breast tumors metastasized to the bone, with antisense inhibition of OPN in human breast cancer cells attenuating osteolytic metastasis $[25,38]$. As well, melanoma cells with OPN expression have a higher rate of lung and bone metastasis when injected into wild-type mice compared to OPN-deficient mice [38, 40].

In the present study, similar to MMP2, OPN expression by tumor cells was not different in bone-invasive meningiomas; however, a significant increase in vascular expression of OPN was seen in transbasal anterior skull base boneinvasive meningiomas. These results, taken together with the MMP2 results, point to bone remodeling being a highly vascular-dependent process and variable based on the anatomical location of meningiomas.

\section{ITGB1}

Integrins are shown to mediate bone metastasis and osteoclast activity in neoplasms of breast and prostate $[4,32,35,41,43$, 47, 50]. They mediate the adhesion of osteoclasts to bone matrix in breast cancer, thereby stimulating the release of lysosomal enzymes that trigger bone collagen degradation [47].

In our study, ITGB1 was the only one of three factors that had a significantly higher expression in tumor cells of transbasal bone-invasive skull base versus anterior skull base 
noninvasive meningiomas. However, similar to MMP2 and OPN, there was no difference in expression in spheno-orbital bone-invasive meningiomas. Once again, these results support the significance of anatomical location governing the difference in biology of transbasal bone invasion versus sphenoorbital meningiomas. Of note is the striking vascular ITGB1 expression found in invasive as well as noninvasive meningiomas, independent of tumor location. ITGB1 stained multiple vascular layers extending from the endothelium through the media and into the adventitia, compared to OPN, which stained only the endothelial cells and MMP2 that stained only the vascular media.

Previous studies focusing on ITGB1 expression in meningiomas are limited to date [4]. Bello et al. [27] found higher ITGB1 expression in atypical and malignant meningioma vasculature as well as tumor cells compared to benign meningiomas. It was noted that tumor vascular ITGB1 immunopositivity was localized to endothelial cells. ITGB1 was also found in vessels present in peritumoral brain tissue, suggesting ITGB1 expression in activated vasculature surrounding tumor tissue, as normal brain tissue is not known to express ITGB1. The significance of ITGB1-mediated pathways was also suggested by the strong correlation between the expression of ITGB1 and vitronectin, an ITGB1-specific ligand required for its activity and promotion of cell migration [27]. This high expression level of ITGB1 in meningiomas makes it a potentially suitable therapeutic target for treatment of unresectable meningiomas.

\section{Conclusions}

This study provides initial insights into the expression profile of proteins involved in bone invasion in skull base bone-invasive meningiomas. Of the three factors investigated, MMP2, OPN, and ITGB1, ITGB1 in transbasal anterior skull base bone-invasive meningiomas was the only factor found to be significantly upregulated. Furthermore, transbasal meningiomas demonstrate significantly higher levels of OPN and ITGB1 expression in the tumor vasculature, suggesting a vasculardependent role for bone invasion in this subset of meningiomas. None of the factors demonstrated significant difference between spheno-orbital bone invasive and their control sphenoid wing meningiomas, whether cytoplasmic or vascular. Our results strongly suggest that the molecular regulators of bone tropism, osteolytic activity, and vascular remodeling of meningiomas is dependent on anatomical location, with transbasal anterior skull base meningiomas showing a distinct differential expression pattern compared to spheno-orbital meningiomas.

Conflicts of interest None.
Open Access This article is distributed under the terms of the Creative Commons Attribution License which permits any use, distribution, and reproduction in any medium, provided the original author(s) and the source are credited.

\section{References}

1. Adwan H, Bauerle TJ, Berger MR (2004) Downregulation of osteopontin and bone sialoprotein II is related to reduced colony formation and metastasis formation of MDA-MB-231 human breast cancer cells. Cancer Gene Ther 11:109-120

2. Al-Mefty O, Smith R (1991) Tuberculum sellae meningiomas. In: AlMefty O (ed) Meningiomas. Raven, Ltd, New York, NY, pp 395-411

3. Barresi V, Caffo M, Ieni A, Alafaci C, Tuccari G (2011) Osteoblastic meningiomas: clinico-pathological and immunohistochemical features of an uncommon variant. J Neurooncol 105:225-232

4. Bello L, Zhang J, Nikas DC, Strasser JF, Villani RM, Cheresh DA, Carroll RS, Black PM (2000) Alpha(v)beta3 and alpha(v)beta5 integrin expression in meningiomas. Neurosurgery 47:1185-1195

5. Bikmaz K, Mrak R, Al-Mefty O (2007) Management of boneinvasive, hyperostotic sphenoid wing meningiomas. J Neurosurg 107:905-912

6. Caers J, Gunthert U, De Raeve H, Van Valckenborgh E, Menu E, Van Riet I, Van Camp B, Vanderkerken K (2006) The involvement of osteopontin and its receptors in multiple myeloma cell survival, migration and invasion in the murine 5 T33MM model. Br J Haematol 132:469-477

7. Carlinfante G, Vassiliou D, Svensson O, Wendel M, Heinegard D, Andersson G (2003) Differential expression of osteopontin and bone sialoprotein in bone metastasis of breast and prostate carcinoma. Clin Exp Metastasis 20:437-444

8. Chandran UR, Ma C, Dhir R, Bisceglia M, Lyons-Weiler M, Liang W, Michalopoulos G, Becich M, Monzon FA (2007) Gene expression profiles of prostate cancer reveal involvement of multiple molecular pathways in the metastatic process. BMC Cancer 7:64

9. Cooper CR, Chay CH, Pienta KJ (2002) The role of alpha(v)beta (3) in prostate cancer progression. Neoplasia 4:191-194

10. Das A, Tan WL, Smith DR (2003) Expression of extracellular matrix markers in benign meningiomas. Neuropathology 23:275-281

11. Duffy MJ, McCarthy K (1998) Matrix metalloproteinases in cancer: prognostic markers and targets for therapy. Int J Oncol 12:1343-1348

12. Fevre-Montange M, Champier J, Durand A, Wierinckx A, Honnorat J, Guyotat J, Jouvet A (2003) Expression of MMP-2 and -9 in shortterm cultures of meningioma: influence of histological subtype. Int $\mathrm{J}$ Mol Med 12:977-981

13. Fisher JL, Schmitt JF, Howard ML, Mackie PS, Choong PF, Risbridger GP (2002) An in vivo model of prostate carcinoma growth and invasion in bone. Cell Tissue Res 307:337-345

14. Hall CL, Dai J, van Golen KL, Keller ET, Long MW (2006) Type I collagen receptor (alpha 2 beta 1) signaling promotes the growth of human prostate cancer cells within the bone. Cancer Res 66:8648-8654

15. Hotte SJ, Winquist EW, Stitt L, Wilson SM, Chambers AF (2002) Plasma osteopontin: associations with survival and metastasis to bone in men with hormone-refractory prostate carcinoma. Cancer 95:506-512

16. Hayashi C, Rittling S, Hayata T, Amagasa T, Denhardt D, Ezura Y, Nakashima K, Noda M (2007) Serum osteopontin, an enhancer of tumor metastasis to bone, promotes B16 melanoma cell migration. J Cell Biochem 101:979-986

17. Hu Z, Lin D, Yuan J, Xiao T, Zhang H, Sun W, Han N, Ma Y, Di X, Gao M, Ma J, Zhang J, Cheng S, Gao Y (2005) Overexpression of osteopontin is associated with more aggressive phenotypes in human non-small cell lung cancer. Clin Cancer Res 11:4646-4652 
18. Ibrahim T, Leong I, Sanchez-Sweatman O, Khokha R, Sodek J, Tenenbaum HC, Ganss B, Cheifetz S (2000) Expression of bone sialoprotein and osteopontin in breast cancer bone metastases. Clin Exp Metastasis 18:253-260

19. Jaalinoja J, Herva R, Korpela M, Hoyhtya M, TurpeenniemiHujanen T (2002) Matrix metalloproteinase 2 (MMP-2) immunoreactive protein is associated with poor grade and survival in brain neoplasms. J Neurooncol 46:81-90

20. Khodavirdi AC, Song Z, Yang S, Zhong C, Wang S, Wu H, Pritchard C, Nelson PS, Roy-Burman P (2006) Increased expression of osteopontin contributes to the progression of prostate cancer. Cancer Res 66:883-888

21. Kirches E, Grunewald J, von Bossanyi P, Szibor R, Plate I, Kruger S, Warich-Kirches M, Dietzmann K (2001) Expression of matrix metalloproteinases in a series of 12 meningiomas. Clin Neuropathol 20:26-30

22. Macri A, Versaci A, Lupo G, Trimarchi G, Tomasello C, Loddo S, Sfuncia G, Caminiti R, Teti D, Famulari C (2009) Role of osteopontin in breast cancer patients. Tumori 95:48-52

23. Moon HS, Jung S, Jung TY, Cao VT, Moon KS, Kim IY (2010) Possible role of matrix metalloproteinase in osteolytic intracranial meningiomas. J Korean Neurosurg Soc 47:11-16

24. Nakasu S, Fukami T, Jito J, Matsuda M (2005) Microscopic anatomy of the brain-meningioma interface. Brain Tumor Pathol 22:53-57

25. Nemoto H, Rittling SR, Yoshitake H, Furuya K, Amagasa T, Tsuji K, Nifuji A, Denhardt DT, Noda M (2001) Osteopontin deficiency reduces experimental tumor cell metastasis to bone and soft tissues. J Bone Miner Res 16:652-659

26. Nordqvist AC, Smurawa H, Mathiesen T (2001) Expression of matrix metalloproteinases 2 and 9 in meningiomas associated with different degrees of brain invasiveness and edema. J Neurosurg 95:839-844. doi:10.3171/jns.2001.95.5.0839

27. Ohyama Y, Nemoto H, Rittling S, Tsuji K, Amagasa T, Denhardt DT, Nifuji A, Noda M (2004) Osteopontin-deficiency suppresses growth of B16 melanoma cells implanted in bone and osteoclastogenesis in co-cultures. J Bone Miner Res 19:1706-1711

28. Okada M, Miyake K, Matsumoto Y, Kawai N, Kunishio K, Nagao S (2004) Matrix metalloproteinase-2 and matrix metalloproteinase9 expressions correlate with the recurrence of intracranial meningiomas. J Neurooncol 66:29-37

29. Okuducu AF, Zils U, Michaelis SA, Michaelides S, von Deimling A (2006) Ets-1 is up-regulated together with its target gene products matrix metalloproteinase- 2 and matrix metalloproteinase- 9 in atypical and anaplastic meningiomas. Histopathology 48:836-845

30. Paek SH, Kim CY, Kim YY, Park IA, Kim MS, Kim DG, Jung HW (2002) Correlation of clinical and biological parameters with peritumoral edema in meningioma. J Neurooncol 60:235-245

31. Panagopoulos AT, Lancellotti CL, Veiga JC, de Aguiar PH, Colquhoun A (2008) Expression of cell adhesion proteins and proteins related to angiogenesis and fatty acid metabolism in benign, atypical, and anaplastic meningiomas. J Neurooncol 89:73-87

32. Pecheur I, Peyruchaud O, Serre CM, Guglielmi J, Voland C, Bourre F, Margue C, Cohen-Solal M, Buffet A, Kieffer N, Clezardin P (2002) Integrin alpha(v)beta3 expression confers on tumor cells a greater propensity to metastasize to bone. FASEB J $16: 1266-1268$

33. Pfisterer WK, Hank NC, Preul MC, Hendricks WP, Pueschel J, Coons SW, Scheck AC (2009) Microarray gene expression profiling in meningiomas: differential expression according to grade or histopathological subtype. Int J Oncol 35:1395-1407

34. Pieper DR, Al-Mefty O, Hanada Y, Buechner D (1999) Hyperostosis associated with meningioma of the cranial base: secondary changes or tumor invasion. Neurosurgery 44:742-747
35. Ports MO, Nagle RB, Pond GD, Cress AE (2009) Extracellular engagement of alpha6 integrin inhibited urokinase-type plasminogen activator-mediated cleavage and delayed human prostate bone metastasis. Cancer Res 69:5007-5014

36. Remmele W, Schicketanz KH (1993) Immunohistochemical determination of estrogen and progesterone receptor content in human breast cancer. Computer-assisted image analysis (QIC score) vs. subjective grading (IRS). Pathol Res Pract 189:862-866

37. Rooprai HK, van Meter TE, Robinson SD, King A, Rucklidge GJ, Pilkington GJ (2011) MMP-9 expression in meningiomas: a prognostic marker for recurrence risk? J Neurooncol 102:189-196

38. Ross FP, Chappel J, Alvarez JI, Sander D, Butler WT, FarachCarson MC, Mintz KA, Robey PG, Teitelbaum SL, Cheresh DA (1993) Interactions between the bone matrix proteins osteopontin and bone sialoprotein and the osteoclast integrin alpha $\mathrm{v}$ beta 3 potentiate bone resorption. J Biol Chem 268:9901-9907

39. Sade B, Chahlavi A, Krishnaney A, Nagel S, Choi E, Lee JH (2007) World Health Organization grades II and III meningiomas are rare in the cranial base and spine. Neurosurgery 61:1194-1198

40. Singhal H, Bautista DS, Tonkin KS, O'Malley FP, Tuck AB, Chambers AF, Harris JF (1997) Elevated plasma osteopontin in metastatic breast cancer associated with increased tumor burden and decreased survival. Clin Cancer Res 3:605-611

41. Sloan EK, Pouliot N, Stanley KL, Chia J, Moseley JM, Hards DK, Anderson RL (2006) Tumor-specific expression of alphavbeta3 integrin promotes spontaneous metastasis of breast cancer to bone. Breast Cancer Res 8:R20

42. Takano S, Yamashita T, Ohneda O (2010) Molecular therapeutic targets for glioma angiogenesis. J Oncol 2010:351908

43. Takayama S, Ishii S, Ikeda T, Masamura S, Doi M, Kitajima M (2005) The relationship between bone metastasis from human breast cancer and integrin alpha(v)beta3 expression. Anticancer Res 25:79-83

44. Tremblay P, Beaudet MJ, Tremblay E, Rueda N, Thomas T, Vallieres L (2004) Diagnostic and prognostic significance of genetic regional heterogeneity in meningiomas. Neuro Oncol 6:290-299

45. Tremblay P, Beaudet MJ, Tremblay E, Rueda N, Thomas T, Vallieres L (2011) Matrix metalloproteinase 2 attenuates brain tumour growth, while promoting macrophage recruitment and vascular repair. J Pathol 224:222-233

46. Tseng KY, Chung MH, Sytwu HK, Lee HM, Chen KY, Chang C, Lin $\mathrm{CK}$, Yen $\mathrm{CH}$, Chen JH, Lin GJ, Yen $\mathrm{CH}$, Chen JH, Lin GJ, Ma HI, Yeh YS, Ju DT, Liu MY, Heung DY (2010) Osteopontin expression is a valuable marker for prediction of short-term recurrence in WHO grade I benign meningiomas. J Neurooncol 100:217-223

47. van der Horst $G$, van den Hoogen C, Buijs JT, Cheung H, Bloys H, Pelger RC, Lorenzon G, Heckmann B, Feyen J, Pujuguet P, Blanque R, Clement-Lacroix P, van der Plujim G (2011) Targeting of alpha (v)-integrins in stem/progenitor cells and supportive microenvironment impairs bone metastasis in human prostate cancer. Neoplasia $13: 516-525$

48. von Randow AJ, Schindler S, Tews DS (2003) Expression of extracellular matrix-degrading proteins in classic, atypical, and anaplastic meningiomas. Pathol Res Pract 202:365-372

49. Wai PY, Kuo PC (2004) The role of osteopontin in tumor metastasis. J Surg Res 121:228-241

50. Zhao Y, Bachelier R, Treilleux I, Pujuguet P, Peyruchaud O, Baron R, Clement-Lacroix P, Clezardin P (2007) Tumor alphavbeta3 integrin is a therapeutic target for breast cancer bone metastases. Cancer Res 67:5821-5830

51. Zhao J, Dong L, Lu B, Wu G, Xu D, Chen J, Li K, Tong X, Dai J, Yao S, Wu M, Guo Y (2008) Down-regulation of osteopontin suppresses growth and metastasis of hepatocellular carcinoma via induction of apoptosis. Gastroenterology 135:956-968 